\title{
Mikrostruktura powłok cermetalowych natryskiwanych metodą płomieniowo-proszkową
}

\section{Microstructure of flame sprayed cermet coatings}

\section{Streszczenie}

W artykule przedstawiono wyniki badań mikrostruktury powłok natryskiwanych metodą płomieniowo-proszkową mieszaninami proszków NiMoAl/ $/ \mathrm{rO}_{2}-30 \% \mathrm{CaO}$ oraz NiAIMo/Al $\mathrm{O}_{3}-40 \% \mathrm{TiO}_{2}$. Skład fazowy określono metodą XRD i wykazano, że w powłoce $\mathrm{ZrO}_{2}-30 \% \mathrm{CaO}$ występują fazy $\mathrm{ZrO}_{2}$ oraz $\mathrm{CaZrO}_{3}$, a w powłoce $\mathrm{Al}_{2} \mathrm{O}_{3}-40 \% \mathrm{TiO}_{2}-\beta$ tytanian glinu, korund, rutyl. Porowatość powłok cermetalowych zależała od składu proszków zastosowanych do natryskiwania. Wartości parametrów struktury geometrycznej powierzchni malały ze wzrastającą zawartością materiału ceramicznego. Dodanie do materiału bazowego tworzącego osnowę cermetalu niewielkiej ilości innego materiału zmienia mechanizm formowania powłoki.

\section{Wstęp}

Zasadniczymi czynnikami wpływającymi na mikrostrukturę powłoki natryskiwanej są: prędkość cząstek i rozkład ich wielkości, temperatura cząstek oraz kąt ich padania. Jeśli cząstki natryskiwane padają pod małym kątem, to tworzona powłoka charakteryzuje się niską przyczepnością. Bardzo istotne jest, aby podczas natryskiwania poddźwiękowego większość cząstek była stopiona. Cząstki, które osiągnęły powierzchnię w stanie stałym, mogą być łatwo oddzielone od powłoki, cząstki częściowo stopione również pogarszają kohezję powłoki. Jeśli temperatura cząstek jest zbyt wyso$\mathrm{ka}$, to następuje ich nadmierne rozpryskiwanie podczas uderzenia w podłoże, co obniża sprawność procesu. Wysoka temperatura cząstki intensyfikuje również utlenianie jej powierzchni [1].

Dr hab. Tadeusz Hejwowski, prof. PL, mgr inż. Anna Łabacz-Kęcik - Politechnika Lubelska.

\section{Abstract}

The paper presents results of microstructural investigations of coatings flame sprayed with the mixtures of powders $\mathrm{NiMoAl} / \mathrm{ZrO}_{2}-30 \% \mathrm{CaO}$ and $\mathrm{NiAlMo} / \mathrm{Al}_{2} \mathrm{O}_{3}-40 \%$ $\mathrm{TiO}_{2}$. Phase composition was evaluated by means of the XRD method. The phases which appear in the $\mathrm{ZrO}_{2}-30 \%$ $\mathrm{CaO}$ coating are $\mathrm{ZrO}_{2}$ and $\mathrm{CaZrO}_{3}$, whereas in the $\mathrm{Al}_{2} \mathrm{O}_{3}-$ $40 \% \mathrm{TiO}_{2}$ coating $-\beta$ aluminium titanate, corundum and rutile. Porosity of cermet coatings depends on the composition of powders used for spraying. The values of parameters describing the geometrical structure of the coating surface decreased with increasing ceramic content. The admixture of low content of other material to the matrixcreating base material changes the mechanism of the coating formation.

W modelu procesu formowania powłoki zakłada się, że stopiona cząstka uderzająca z dużą prędkością w powierzchnię podłoża rozpłaszcza się, tworząc dysk, jednak proces radialnego płynięcia nie jest stabilny i dlatego na brzegu dysku tworzą się, niewielkie krople materiału. Krzepnięcie materiału hamuje proces tworzenia się dysku. Prędkość chłodzenia materiału natryskiwanego wynosi ok. $10^{6} \mathrm{~K} / \mathrm{s}$. Krystalizacja cząstek powłoki następuje przez powstanie i rozwój zarodka. Powierzchnia styku utworzonej lamelli z sąsiednimi lamellami jest niewielka, dużą część powierzchni kontaktu zajmują pory oraz tlenki. Rozkład wielkości porów jest bimodalny, pory o większych rozmiarach powstają wskutek niedopasowania tworzącej się lamelli do topografii podłoża. Obecność mniejszych porów o wielkości ok. 0,1 $\mu \mathrm{m}$ jest cechą charakterystyczną procesu natryskiwania [2]. Badania mikrostruktury wykazują również istnienie pęknięć w powłoce prostopadłych do podłoża (segmentation cracks), powstałych w materiale ceramicznym wskutek naprężeń cieplnych w czasie stygnięcia powłoki. Badania mikrostruktur powłok natryskiwanych metodą plazmową $\mathrm{Al}_{2} \mathrm{O}_{3}$ wykazały, że rzeczywista powierzchnia kontaktu lamelli 
wynosi $10 \div 32 \%$, zależnie od parametrów procesu natryskiwania. W przypadku natryskiwanej metodą detonacyjną powłoki $\mathrm{Al}_{2} \mathrm{O}_{3}$ efektywna powierzchnia styku wynosi ok. 10\% powierzchni lamelli [3, 4]. Obecność pęknięć i porów w powłoce silnie wpływa na jej właściwości, powodując zmniejszenie wartości modułu Younga i współczynnika przewodzenia ciepła.

Gwałtowne chłodzenie lamelli podczas natryskiwania sprzyja powstawaniu faz metastabilnych, przesyconych roztworów oraz struktury polikrystalicznej o znacznie wyższym stopniu dyspersji niż materiałów konwencjonalnych.

Chemicznie czysty $\mathrm{ZrO}_{2}$ wykazuje polimorfizm, zachodząca podczas zmiany temperatury przemiana fazowa jest związana ze znaczną zmianą objętości, co powoduje pękanie ceramiki. W celu wykluczenia przemian fazowych stosuje się domieszki $\mathrm{Y}_{2} \mathrm{O}_{3}, \mathrm{MgO}, \mathrm{CeO}_{2}$ lub CaO. Główne zastosowanie częściowo stablizowanego $\mathrm{ZrO}_{2}$ stanowią bariery cieplne.

Powłoki natryskiwane mieszaninami $\mathrm{Al}_{2} \mathrm{O}_{3}-\mathrm{TiO}_{2}$ charakteryzują się wysoką odpornością na zużycie ścierne, erozyjne i kawitacyjne. Stosowane są również natryskiwane plazmowo bariery cieplne na bazie $\mathrm{Al}_{2} \mathrm{O}_{3}-$ $40 \% \mathrm{TiO}_{2}$ na denkach tłoków silników wysokoprężnych oraz iskrowych [5].

Wadą materiałów ceramicznych jest ich kruchość. Materiał ceramiczny może również wykazywać wysoką transmisję światła w zakresie podczerwieni. Zastosowanie powłok kompozytowych zawierających oprócz fazy ceramicznej również fazę metaliczną może stanowić rozwiązanie tego problemu. W spiekanych materiałach kompozytowych ziarna metaliczne powodują „mostkowanie” ścian pęknięcia, a także obniżenie współczynnika intensywności naprężeń przy wierzchołku pęknięcia [6]. Powłoki cermetalowe natryskiwane plazmowo mieszaniną CoNiCrAlY/AI $\mathrm{O}_{3}$ oraz mieszaniną $\mathrm{NiAl} / \mathrm{Al}_{2} \mathrm{O}_{3}$ wykazują wysoką odporność na zużycie erozyjne $[7,8]$. Udziały fazy metalicznej i fazy ceramicznej mogą być tak dobrane, aby uzyskać maksimum odporności na erozję dla założonego kąta padania ścierniwa [9].

Mikrostruktura powłok cermetalowych natryskiwanych metodą płomieniowo-proszkową była dotychczas przedmiotem bardzo nielicznych i fragmentarycznych badań. W pracy przedstawiono wyniki badań właściwości powłok cermetalowych natryskiwanych metodą płomieniowo-proszkową mieszaninami proszków $\mathrm{NiMoAl} / \mathrm{ZrO}_{2}-30 \%$ mas. $\mathrm{CaO}$ oraz $\mathrm{NiMoAl} / \mathrm{Al}_{2} \mathrm{O}_{3}-40 \%$ mas. $\mathrm{TiO}_{2}$. Źbadano zależność parametrów charakteryzujących strukturę geometryczną powierzchni od składu chemicznego powłoki. Określono skład fazowy powłok, nanotwardość oraz porowatość.

\section{Metodyka badań}

Próbki ze stali S235JR przed natryskiwaniem poddano obróbce strumieniowo-ściernej luźnym ścierniwem korundowym o wielkości ziarna 70, na własnym stanowisku. Powłoki wykonano metodą natryskiwania płomieniowo-proszkowego poddźwiękowego palnikiem UNI-SPRAY-JET firmy Amil. Warstwę wiążącą natryskiwano proszkiem AMI $3452.6 \mathrm{NiMoAl}(\mathrm{Al}=5,2 \%$; $\mathrm{Mo}=4,9 \% ; \mathrm{Fe}=0,8 \%$; $\mathrm{Si}=0,4 \%$; $\mathrm{Ni}$ - reszta) o wielkości ziarna $-125+45 \mu \mathrm{m}$.

Warstwy cermetalowe natryskiwano mieszaniną proszków zawierającą AMI 3452.6 oraz UTP $\mathrm{MX}$ 6-3018 $\left(\mathrm{Al}_{2} \mathrm{O}_{3}-40 \% \quad \mathrm{TiO}_{2}\right.$, o wielkości ziarna $-45+15 \mu \mathrm{m},-$ proszek A) lub UTP MX 3-3020 $\left(\mathrm{ZrO}_{2}-30 \% \mathrm{CaO}\right.$, o wielkości ziarna $-45+15 \mu \mathrm{m}$ - proszek B). Przygotowaną mieszaninę proszków podawano do palnika w strumieniu argonu z własnego podajnika fluidalnego. Parametry natryskiwania powłok z mieszaniny proszków były zgodne z zalecanymi do natryskiwania powłoki z proszków ceramicznych. Grubość warstwy cermetalowej wynosiła ok. 0,3 mm. Zawartość proszku ceramicznego była zmieniana w zakresie $0 \div 100 \%$. Przedstawione badania stanowią część wykonywanych prac, których celem jest określenie możliwości zastosowania natryskiwanych metodą płomieniowo-proszkową powłok cermetalowych do wytwarzania wielowarstwowych barier cieplnych lub do zwiększania odporności elementów przemysłowych na erozję.

Powłoki impregnowano żywicą epoksydową przed cięciem na przecinarce metalograficznej. Fotografie zgładów metalograficznych wykonano za pomocą mikroskopu świetlnego Nikon Eclipse MA100 wyposażonego w kamerę cyfrową. Badania metalograficzne ilościowe wykonano, używając programu Image J, analizowano 10 zdjęć każdej powłoki. Wykonano również badania na mikroskopie skaningowym Zeiss Ultra Plus. Badaniom SEM poddano powierzchnie powłok natryskiwanych oraz powierzchnie przełomów otrzymanych w próbie zginania próbek pokrytych powłokami.

Analizę składu fazowego wykonano na powierzchni natryskiwanych powłok za pomocą dyfraktometru rentgenowskiego HZG-4 metodą Bragga-Brentano. Wykorzystano promieniowanie $\mathrm{CuK}_{\alpha}$. Dane pomiarowe były zbierane i opracowywane za pomocą programu XRAYAN. Pomiary chropowatości wykonano na przyrządzie do pomiaru kształtów i chropowatości Form Talysurf 120 Inductive firmy Taylor Hobson. Końcówkę pomiarową stanowił diament w kształcie stożka o kącie wierzchołkowym $90^{\circ}$ i promieniu zaokrąglenia ostrza $2 \mu \mathrm{m}$. Analizę fraktalną wykonano za pomocą programów Benoit 1.3 i Tisean, wykorzystano pliki ze współrzędnymi punktów tworzących profil powierzchni.

Pomiary nanotwardości wykonano za pomocą nanotwardościowmierza CSM NHT. Maksymalne obciążenie wgłębnika Vickersa wynosiło $150 \mathrm{mN}$, czas utrzymywania stałego obciążenia był równy $10 \mathrm{~s}$. Moduł Younga został obliczony wg modelu Olivera Pharra przy założeniu wartości współczynnika Poissona $v=0,3$. 


\section{Wyniki badań i dyskusja}

Dyfraktogramy otrzymane w badaniach składu fazowego powłok natryskiwanych przedstawiono na rysunkach $1 \div 5$. Badania składu fazowego powłoki natryskiwanej proszkiem AMI 3452.6 ujawniły głównie roztwór stały niklu krystalizujący w układzie regularnym powierzchniowo centrowanym oraz $\mathrm{NiO}$ w układzie heksagonalnym (rys. 1). Uzyskane wyniki są zbliżone do obserwowanych w pracach $[10,11]$.

Mikrostruktura powłoki natryskiwanej UTP MX 6-3018 $\left(\mathrm{Al}_{2} \mathrm{O}_{3}-40 \%\right.$ mas. $\left.\mathrm{TiO}_{2}\right)$ zawiera $\beta$ tytanian glinu $\mathrm{Al}_{2} \mathrm{TiO}_{5}$ (układ ortorombowy) oraz $\mathrm{w}$ znacznie mniejszych zawartościach $\mathrm{Al}_{2} \mathrm{O}_{3}$ (korund, układ heksagonalny) $\mathrm{i} \mathrm{TiO}_{2}$ (rutyl, układ tetragonalny) (rys. 2). Skład fazowy jest zbliżony do powłok natryskiwanych metodą plazmową [12] i jest związany z dużą prędkością chłodzenia cząstek tworzących powłokę $\left(10^{5} \div 10^{6} \mathrm{~K} / \mathrm{s}\right)$ [13]. $\beta$ tytanian glinu $\mathrm{Al}_{2} \mathrm{TiO}_{5}$ charakteryzuje się dużą odpornością na zmęczenie cieplne.

Mikrostruktura powłoki natryskiwanej proszkiem $\mathrm{ZrO}_{2}-30 \%$ mas. CaO składa się z $\mathrm{ZrO}_{2}$ oraz $\mathrm{CaZrO}_{3}$

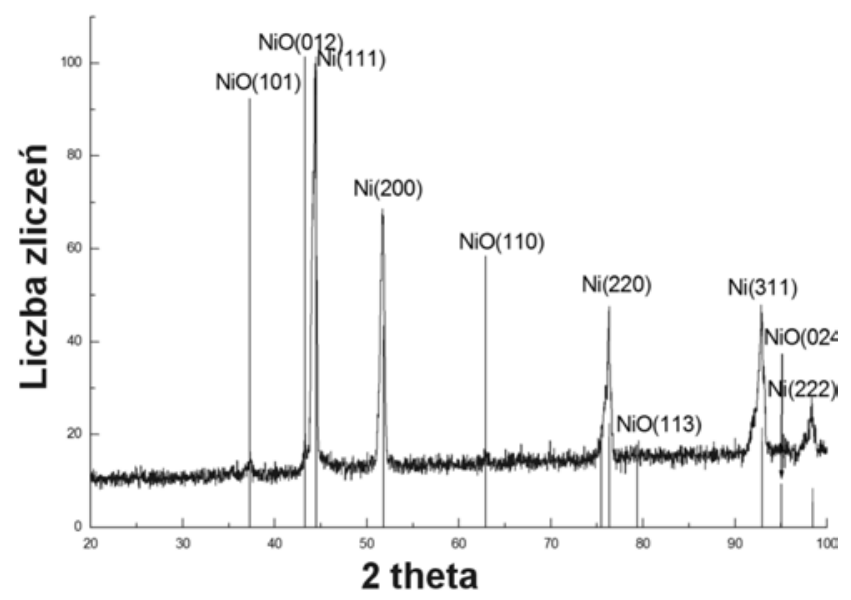

Rys. 1. Dyfraktogram powłoki natryskiwanej proszkiem AMI 3452.6 Fig. 1. XRD pattern of coating sprayed with AMI 3452.6

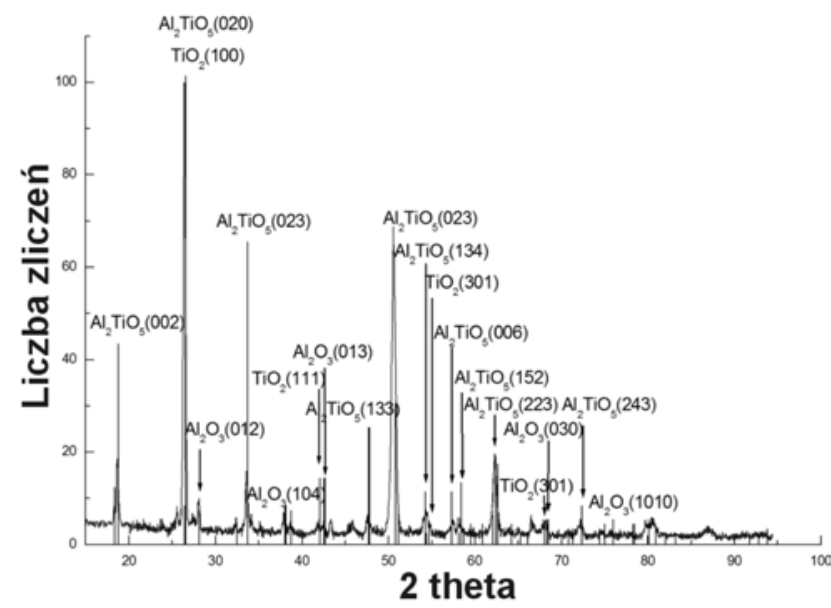

Rys. 2. Dyfraktogram powłoki natryskiwanej proszkiem UTP MX 6-3018

Fig. 2. XRD pattern of coating sprayed with UTP MX 6-3018 krystalizujących w układzie ortorombowym (rys. 3). Zawartość tlenku stabilizującego $\mathrm{CaO} w$ badanej powłoce była znacznie większa od zwykle stosowanej [14].

Dyfraktogramy powłok cermetalowych przedstawiono na rysunku 4 i 5 . Możliwość występowania

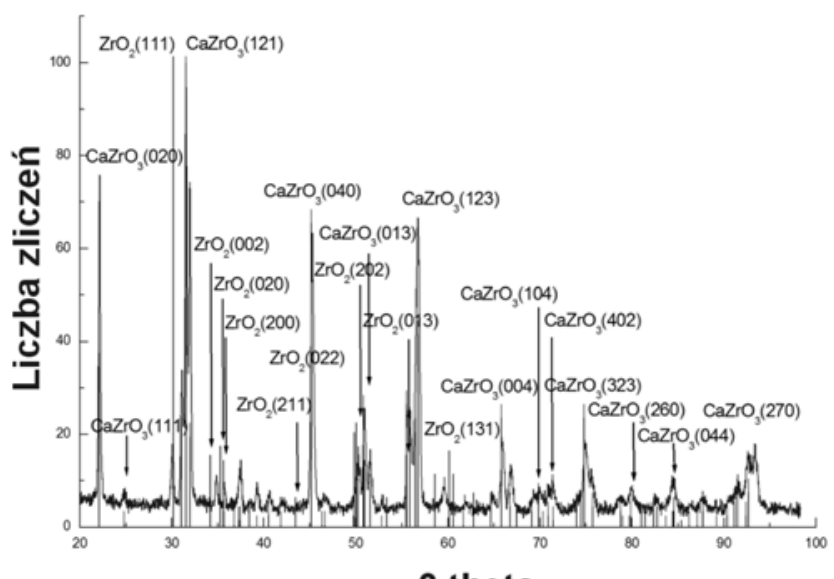

\section{2 theta}

Rys. 3. Dyfraktogram powłoki natryskiwanej proszkiem UTP MX 3-3020

Fig. 3. XRD pattern of coating sprayed with UTP MX 3-3020

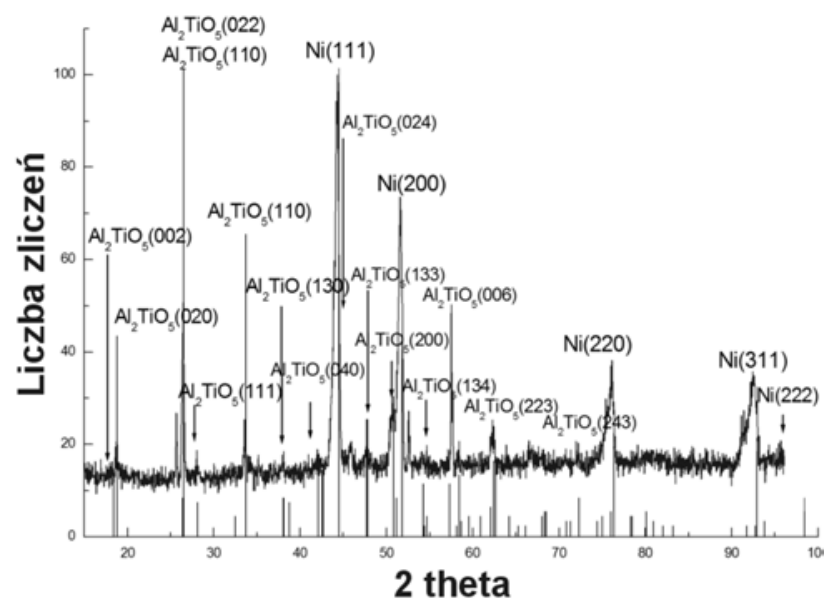

Rys. 4. Dyfraktogram powłoki natryskiwanej mieszaniną proszków zawierającą 50\% mas. UTP MX 6-3018

Fig. 4. XRD pattern of coating sprayed with powder mixture containing 50 wt. \% UTP MX 6-3018

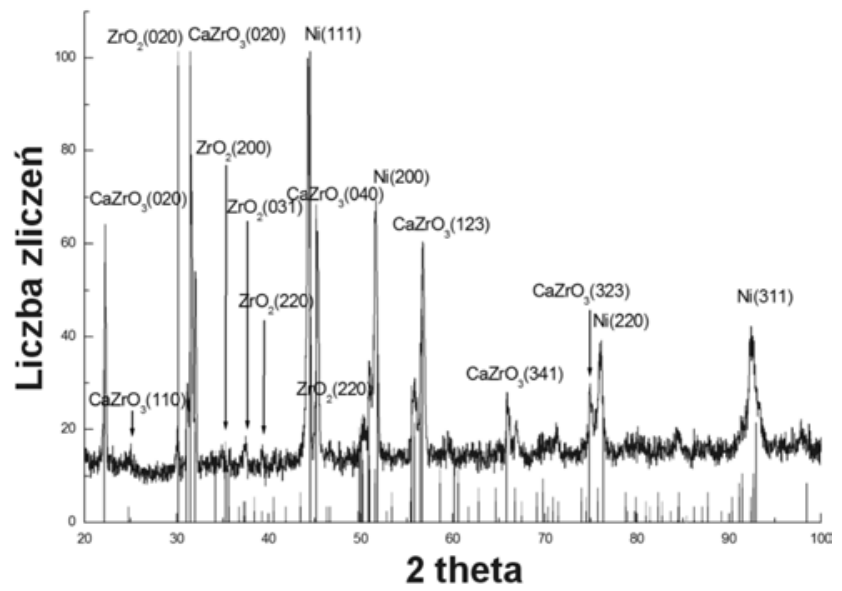

Rys. 5. Dyfraktogram powłoki natryskiwanej mieszaniną proszków zawierającą 50\% mas. UTP MX 3-3020

Fig. 5. XRD pattern of coating sprayed with powder mixture containing 50 wt. \% UTP MX 6-3020 
reakcji chemicznej pomiędzy fazą ceramiczną i metaliczną stwierdzono w [15]. w przedstawionej pracy nie zauważono obecności podobnych efektów i dyfraktogramy powłok cermetalowych są superpozycją dyfraktogramu zarejestrowanego dla powłoki natryskiwanej materiałem wiążącym oraz dyfraktogramu powłoki natryskiwanej proszkiem ceramicznym.

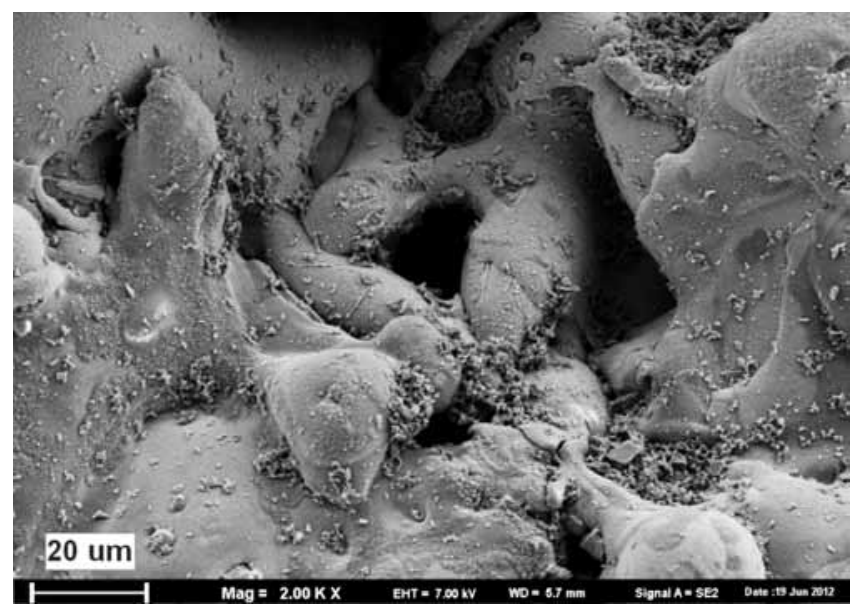

Rys. 6. Powierzchnia powłoki natryskiwanej proszkiem AMI 3452.6

Fig. 6. Surface of coating sprayed with AMI 3452.6

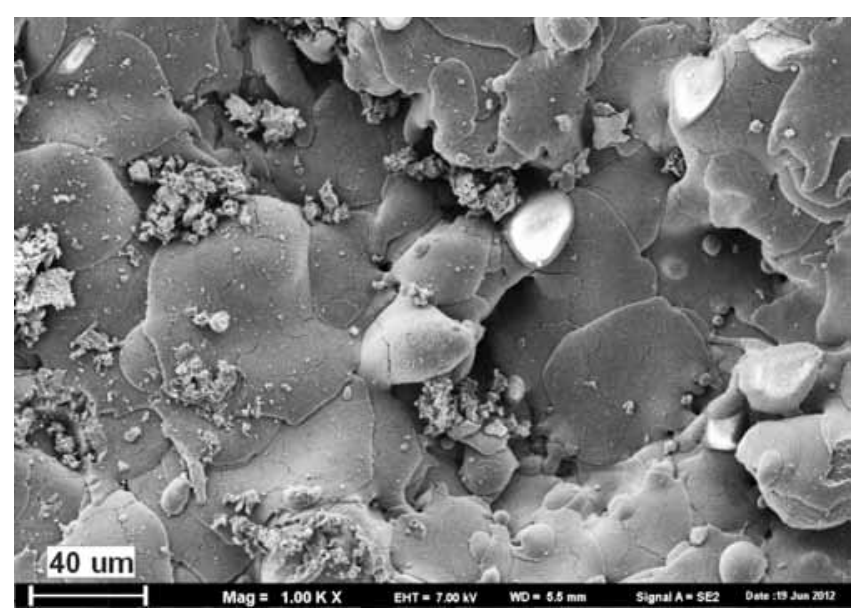

Rys. 7. Powierzchnia powłoki natryskiwanej proszkiem UTP MX 6-3018, SEM

Fig. 7. Surface of coating sprayed with UTP MX 6-3018, SEM

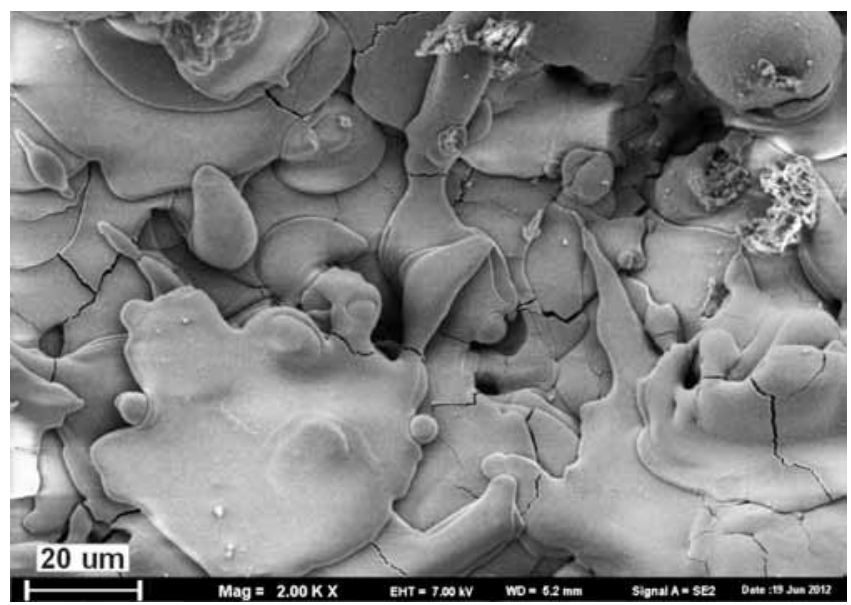

Rys. 8. Powierzchnia powłoki natryskiwanej proszkiem MX 3-3020, SEM

Fig. 8. Surface of coating sprayed with MX 3-3020, SEM
Powierzchnie powłok natryskiwanych przedstawiono na rysunkach $6 \div 8$. Powierzchnia powłoki natryskiwanej materiałem podkładowym jest typowa dla powłok natryskiwanych (rys. 6). Nie występują w niej pęknięcia w ziarnach powłoki, widać też jej porowatość otwartą.

W ziarnach powłoki natryskiwanej UTP MX 6-3018 widoczne są mikropęknięcia powstałe podczas stygnięcia powłoki i związane z dużą anizotropią współczynników rozszerzalności cieplnej dominującej fazy $\beta$ - tytanianu glinu $\mathrm{Al}_{2} \mathrm{TiO}_{5}$ (rys. 7).

$\mathrm{Na}$ powierzchni powłoki natryskiwanej proszkiem MX 3-3020 widać mikropęknięcia prostopadłe do powierzchni (rys. 8). Pęknięcia mogą powstać w czasie stygnięcia lamelli wskutek naprężeń występujących podczas schładzania. Można zauważyć ziarna o kształcie zbliżonym do sferycznego, utworzone przez cząstki, które były częściowo stopione w chwili uderzenia w podłoże.

Obraz powierzchni przełomu powstałego w próbie zginania powłoki zawierającej 50\% mas. MX 6-3018 wskazuje na mostkowanie przez cząstki metaliczne. Pęknięcie przebiega częściowo po granicy cząstek, a częściowo przez cząstki ceramiczne (rys. 9). Mikrostrukturę powłoki przedstawiono na rysunku 10. Grubość lamelli jest większa niż grubość lamelli w powłoce natryskiwanej metodą plazmową ze względu na mniejszą prędkość cząstek i temperaturę [1].

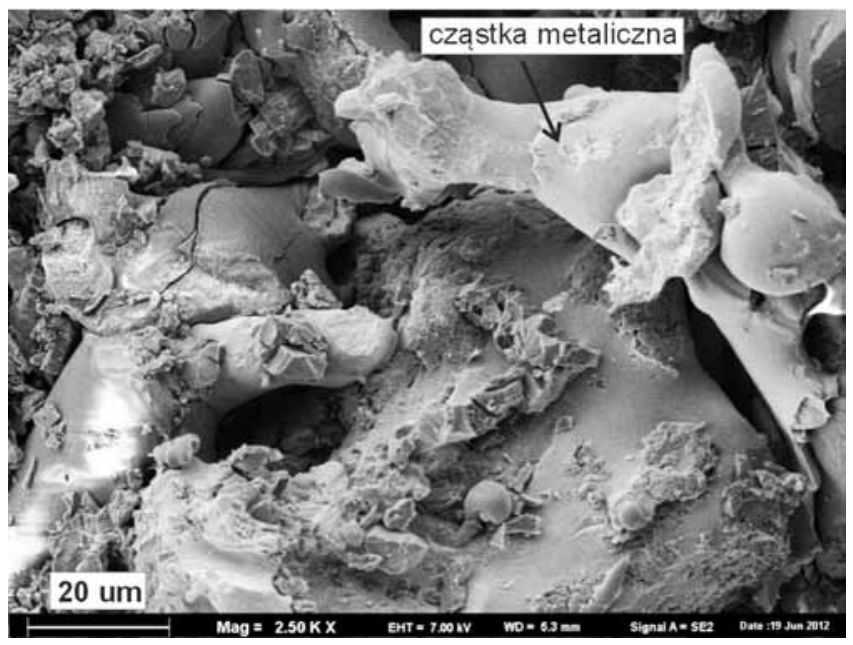

Rys. 9. Powierzchnia przełomu powłoki natryskiwanej mieszaniną proszków zawierającą 50\% mas. UTP MX 6-3018

Fig. 9. Fracture surface of coating sprayed with powder mixture containing 50 wt. \% UTP MX 6-3018

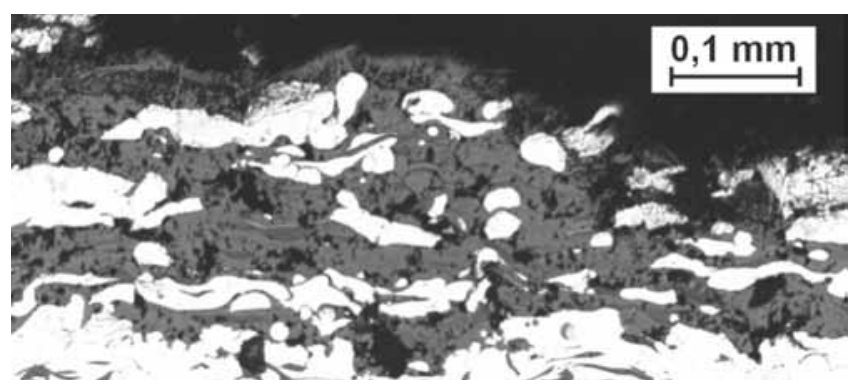

Rys. 10. Mikrostruktura powłoki zawierającej 50\% mas. MX 6-3018, pow. $120 \mathrm{x}$

Fig. 10. Microstructure of coating containing 50 wt. \% MX 6-3018, magn. $120 x$ 
Tablica. Wyniki pomiarów nanotwardości powłok

Table. Results of hardness investigation of coatings

\begin{tabular}{|c|c|c|c|c|}
\hline \multirow{2}{*}{ Powłoka } & \multicolumn{2}{|c|}{ Nanotwardość, HV } & \multicolumn{2}{c|}{ Moduł Younga, GPa } \\
\cline { 2 - 5 } & zakres & $\begin{array}{c}\text { wartość } \\
\text { średnia }\end{array}$ & zakres & $\begin{array}{c}\text { wartość } \\
\text { średnia }\end{array}$ \\
\hline AMI 3452.6 & $284,3 \div 387,8$ & 327,9 & $94,3 \div 182,1$ & 115,1 \\
\hline UTP MX-3018 & $415,2 \div 1274,1$ & 727,1 & $85,5 \div 144,9$ & 109,2 \\
\hline UTP MX-3020 & $257,7 \div 1520,3$ & 449,5 & $81 \div 113,8$ & 95,1 \\
\hline
\end{tabular}

Wyniki pomiarów nanotwardości wykonane na zgładach poprzecznych powłok przedstawiono $\mathrm{w}$ tablicy. Wykonane odciski w próbie nanotwardości mieściły się w obrębie jednej lamelli powłoki. Wartości pomiarów nanotwardości ziaren ceramicznych różniły się znacznie ze względu na występowanie różnych faz w obrębie tego samego ziarna powłoki. Zakres wartości mierzonych właściwości wyznaczono na podstawie 20 punktów pomiarowych. Nie stwierdzono występowania istotnych różnic $w$ zakresach nanotwardości cząstek metalicznych i ceramicznych mierzonych na zgładach powłok, spowodowanych składem chemicznym powłoki. Moduł Younga natryskiwanego plazmowo $\mathrm{ZrO}_{2}-8 \%$ mas. $\mathrm{Y}_{2} \mathrm{O}_{3}$ wyznaczony metodą zginania czteropunktowego wynosi $2,5 \div 20 \mathrm{GPa}$ i zależy od gęstości pęknięć prostopadłych do powierzchni [16]. Przyczyną rozbieżności z prezentowaną pracą jest wpływ pęknięć i porów na wyniki próby zginania. W opracowaniu [17] stwierdzono, że twardość natryskiwanej plazmowo powłoki zależy od jej składu chemicznego i ze względu na różną porowatość badanych powłok wynosi $4 \div 5,5 \mathrm{GPa}$. Wartości modułu Younga i twardości warstwy wiążącej uzyskane w pracy są zbliżone do wyznaczonych dla powłok natryskiwanych metodą APS [18]. Zbieżne wyniki uzyskano także dla powłok natryskiwanych $\mathrm{Al}_{2} \mathrm{O}_{3}-40 \%$ mas. $\mathrm{TiO}_{2}$ [19].

Wyniki pomiarów porowatości przedstawiono na rysunku 11 i 12 . Porowatości powłok natryskiwanych proszkami ceramicznymi są wyraźnie wyższe od porowatości powłoki natryskiwanej proszkiem metalicznym. Zwiększanie udziału proszku ceramicznego do zawartości $50 \%$ mas. UTP MX $6-3018$ oraz $40 \%$ mas. w przypadku mieszaniny zawierającej UTP MX 6-3020 powoduje zmniejszenie porowatości powłoki. Wprowadzenie do proszku ceramicznego materiału metalicznego o zawartości $10 \div 20 \%$ mas. powoduje wyraźne obniżenie porowatości.

W badaniach natryskiwanych plazmowo powłok cermetalowych wykazano, że dla małej zawartości fazy ceramicznej w proszku cząstki metaliczne po uderzeniu w powierzchnię ulegały spłaszczeniu, natomiast dla dużych udziałów fazy ceramicznej miały inny kształt i były „wciśnięte” pomiędzy cząstki ceramiczne powłoki [20]. Zwiększenie zawartości ceramiki w powłoce zmniejsza przewodnictwo cieplne powłoki i zwiększa temperaturę powierzchni natryskiwane.j Wykazano, że kształt tworzącej się cząstki powłoki silnie zależy od temperatury podłoża [21]. Podane mechanizmy moga mieć wpływ na proces formowania się natryskiwanej płomieniowo powłoki cermetalowej.

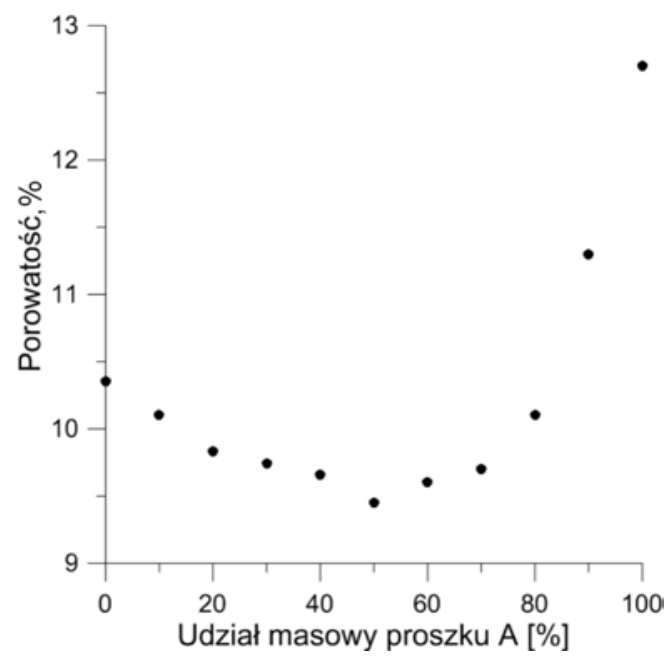

Rys. 11. Zależność porowatości od składu powłoki natryskiwanej mieszaniną proszków zawierającą UTP MX 6-3018

Fig. 11. Dependence of porosity on coating composition sprayed with mixture containing UTP MX 6-3018

Właściwości materiałów natryskiwanych mają bardzo istotny wpływ na proces powstawania powłoki:

- $\mathrm{Al}_{2} \mathrm{O}_{3}-40 \%$ mas. $\mathrm{TiO}_{2}$ ma temperature topnienia ok. $1840^{\circ} \mathrm{C}$, gęstość ok. $3700 \mathrm{~kg} / \mathrm{m}^{3}$, współczynnik rozszerzalności cieplnej poniżej $1 \cdot 10^{-6} 1 / \mathrm{K}$ i ciepło właściwe $800 \mathrm{~J} /(\mathrm{kg} \cdot \mathrm{K})$,

- $\mathrm{ZrO}_{2}-30 \%$ mas. $\mathrm{CaO}$ ma temperaturę topnienia $2340^{\circ} \mathrm{C}$, gęstość $4900 \mathrm{~kg} / \mathrm{m}^{3}$, współczynnik rozszerzalności ok. $1 \cdot 10^{-5} 1 / \mathrm{K}$ i ciepło właściwe ok. $400 \mathrm{~J} /(\mathrm{kg} \cdot \mathrm{K})$,

- Ni-Al ma temperaturę topnienia $1425^{\circ} \mathrm{C}$ gęstość $8000 \mathrm{~kg} / \mathrm{m}^{3}$, współczynnik rozszerzalności $19 \cdot 10^{-6} 1 / \mathrm{K}$ i ciepło właściwe $450 \mathrm{~J} /(\mathrm{kg} \cdot \mathrm{K})$.

Materiały UTP MX 6-3018 i UTP MX 6-3020 znacznie różnią się temperaturą topnienia oraz wartościami współczynnika rozszerzalności cieplnej. W związku z tym można oczekiwać istotnej różnicy w odporności na zużycie powłok cermetalowych wykonywanych z tych materiałów. Znaczna różnica we współczynniku rozszerzalności cieplnej fazy

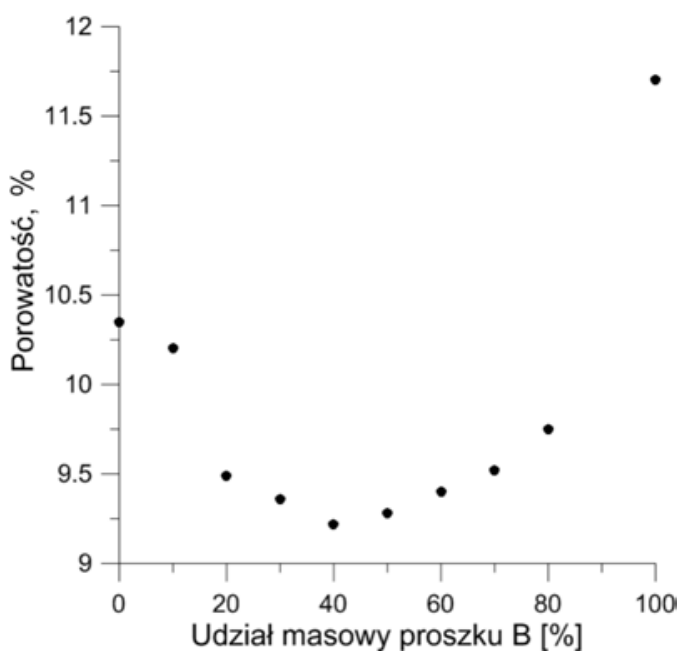

Rys. 12. Zależność porowatości od składu powłoki natryskiwanej mieszaniną proszków zawierającą UTP MX 6-3020

Fig. 12. Dependence of porosity on coating composition sprayed with mixture containing UTP MX 6-3020 


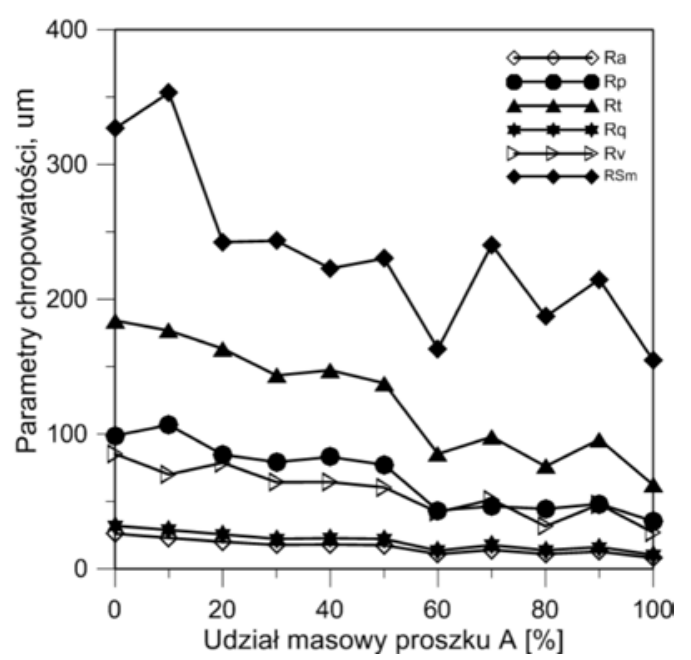

Rys. 13. Zależność parametrów struktury geometrycznej powierzchni od składu powłoki natryskiwanej mieszaniną proszków zawierającą UTP MX 6-3018

Fig. 13. Dependence of surface geometrical parameters on composition of coating sprayed with powder mixture containing UTP MX 6-3018

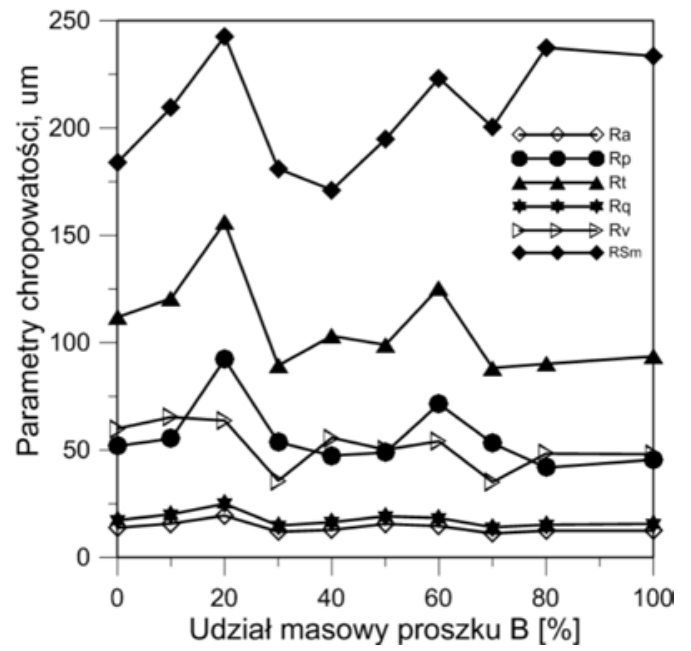

Rys. 14. Zależność parametrów struktury geometrycznej powierzchni od składu powłoki natryskiwanej mieszaniną proszków zawierająca UTP MX 6-3020

Fig. 14. Dependence of surface geometrical parameters on composition of coating sprayed with powder mixture containing UTP MX 6-3020

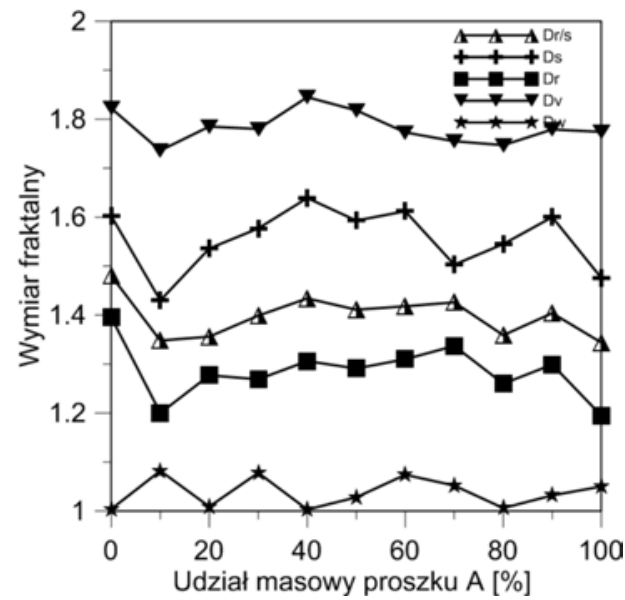

Rys. 15. Zależność wymiarów fraktalnych od składu powłoki natryskiwanej mieszaniną proszków zawierającą UTP MX 6-3018

Fig. 15. Dependence of fractal dimensions on composition of coating sprayed with powder mixture containing UTP MX 6-3018 ceramicznej oraz metalicznej pogarsza kohezję powłoki cermetalowej. Zaobserwowane w lamellach powłoki natryskiwanej proszkiem UTP MX 6-3018 mikropęknięcia mogą ułatwić usuwanie ziaren ceramicznych w badaniach zużycia.

Parametry chropowatości powłoki cermetalowej zawierającej UTP MX 6-3018 pogarszają się z rosnącą zawartością proszku ceramicznego, którego ziarna mają mniejszą średnicę, ale wyższą temperaturę topnienia (rys. 13). W powłoce zawierającej UTP MX 6-3020 parametry maleją, z wyjątkiem Rsm (średnia szerokość rowków elementów profilu), ze wzrastającym udziałem ceramiki (rys. 14).

Analiza fraktalna jest metodą opisu struktury powierzchni komplementarną do metod tradycyjnych. Parametry fraktalne opisują zarówno wysokość nierówności, jak i ich kształt. Metody fraktalne były stosowane do: scharakteryzowania chropowatości powłok z częściowo stabilizowanego tlenku cyrkonu natapianych metodą laserową [22], charakteryzowania porowatości powłok nakładanych metodą hybrydową płomieniowo-laserową [23], badania związku pomiędzy odpornością na pękanie i strukturą geometryczną powierzchni przełomu [24], związku pomiędzy odpornością na pękanie kompozytów ceramicznych i drogą rozwoju pęknięcia [25]. Stwierdzono również związek pomiędzy przyczepnością i parametrami fraktalnymi opisującymi powierzchnię podłoża [26, 27]. W badaniach powłok $\mathrm{Ti}+\mathrm{Ti}(\mathrm{C}, \mathrm{N})$ nanoszonych metodą magnetronową stwierdzono, że większa wartość wymiaru fraktalnego powierzchni określonego metodą projective covering method odpowiada wyższej twardości powłok [28]. Na podstawie wyników cytowanych prac można sformułować tezę, że określenie wymiaru fraktalnego powłok cermetalowych daje informację na temat kohezji powłok.

Wymiary fraktalne określono następującymi metodami: analizy R/S (Dr/s), power spectrum (Ds), roughness-length (Dr), metodą wariogramu (Dv) oraz metodą wavelets (Dw). Wymiar korelacyjny d2 określono metodami AMI (Average Mutual Information) oraz FNM (False Nearest Neighbours Method). Wyniki obliczeń podano na rysunkach $15 \div 20$.

Nie stwierdzono występowania korelacji pomiędzy wymiarem fraktalnym powierzchni powłok i porowatością dla obu typów powłok. Dodawanie do mieszaniny proszku o małym ziarnie powinno systematycznie obniżać wartość wymiaru fraktalnego [29]. Wartość wymiaru fraktalnego jest miarą stopnia rozwinięcia powierzchni, ale zależy od metody obliczania. Duże zmiany wartości wymiaru fraktalnego spowodowane niewielką zawartością materiału ceramicznego wskazują na zmianę mechanizmu formowania powłoki. Należy pamiętać, że pomiar profilu powierzchni powłok metodą kontaktową wprowadza systematyczny błąd pomiarowy ze względu na docisk końcówki pomiarowej i jej kształt.

Analizowane szeregi, ze względu na wartość współczynnika Hursta > 0,5 mm, można nazwać perystentnymi ze względu na obecność trendów w analizowanych danych. 


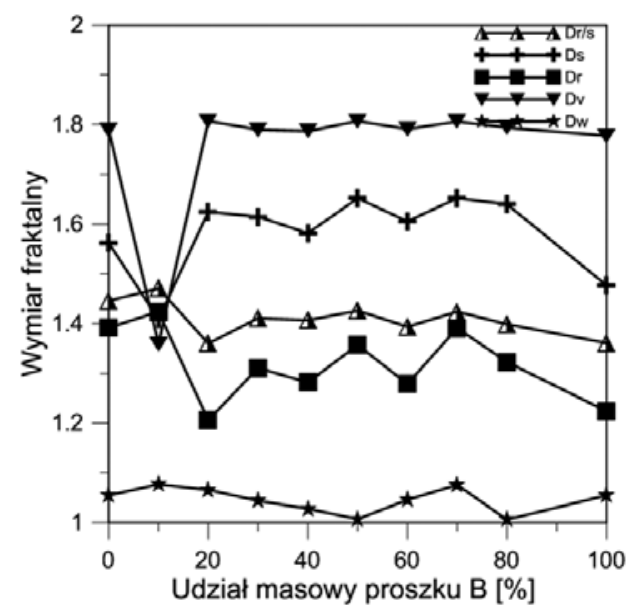

Rys. 16. Zależność wymiarów fraktalnych od składu powłoki natryskiwanej mieszaniną proszków zawierającą UTP MX 6-3020

Fig. 16. Dependence of fractal dimensions on composition of coating sprayed with powder mixture containing UTP MX 6-3020

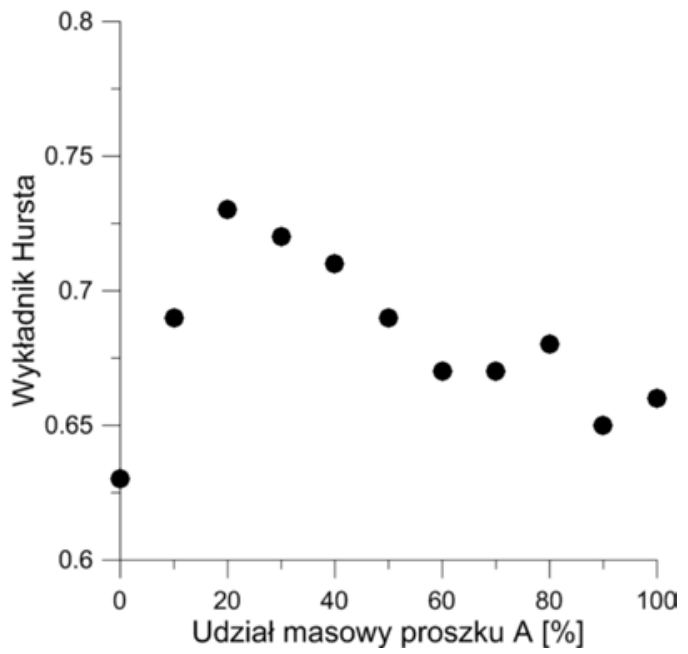

Rys. 17. Zależność wykładnika Hursta od składu powłoki natryskiwanej mieszaniną proszków zawierającą UTP MX 6-3018

Fig. 17. Dependence of Hurst exponent on composition of coating sprayed with powder mixture containing UTP MX 6-3018

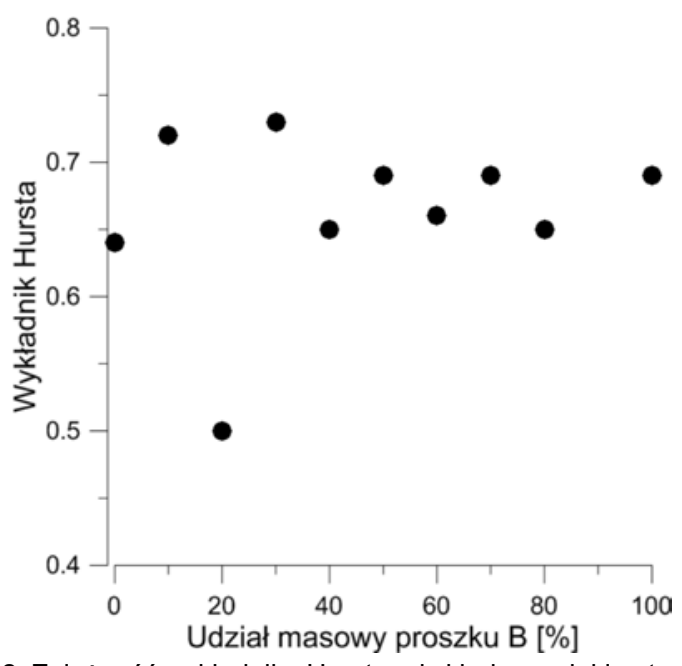

Rys. 18. Zależność wykładnika Hursta od składu powłoki natryskiwanej mieszaniną proszków zawierającą UTP MX 6-3020

Fig. 18. Dependence of Hurst exponent on composition of coating sprayed with powder mixture containing UTP MX 6-3020

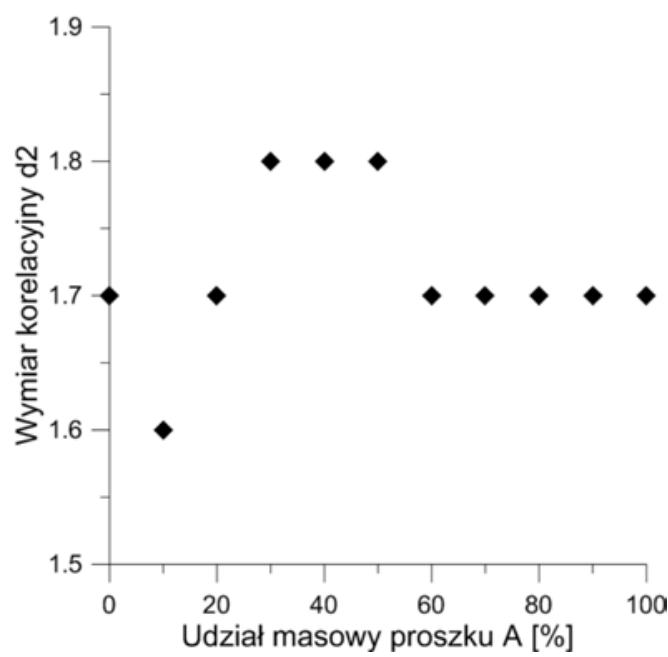

Rys. 19. Zależność wymiaru korelacyjnego d2 od składu powłoki natryskiwanej mieszaniną proszków zawierającą UTP MX 6-3018

Fig. 19. Dependence of $d 2$ correlation dimension on composition of coating sprayed with powder mixture containing UTP MX 6-3018

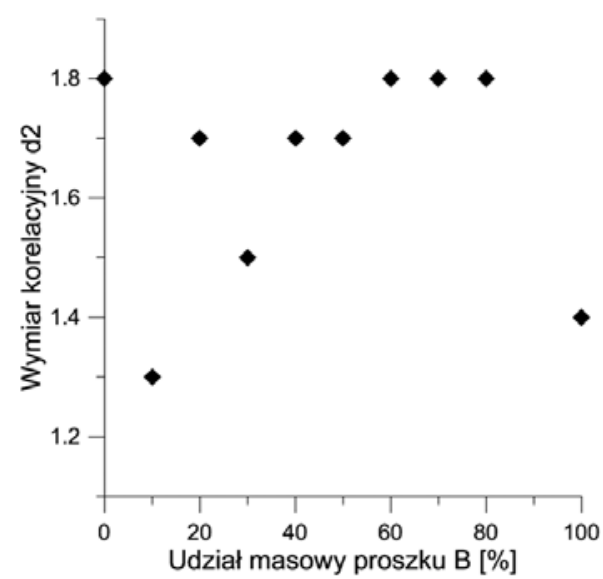

Rys. 20. Zależność wymiaru korelacyjnego d2 od składu powłoki natryskiwanej mieszaniną proszków zawierającą UTP MX 6-3020

Fig. 20. Dependence of $\mathrm{d} 2$ correlation dimension on composition of coating sprayed with powder mixture containing UTP MX 6-3020

\section{Wnioski}

W natryskiwanych powłokach cermetalowych występują następujące fazy:

- powłoka NiMoAl/ $\mathrm{Al}_{2} \mathrm{O}_{3}-40 \%$ mas. $\mathrm{TiO}_{2}$ : roztwór stały $\mathrm{Ni}, \mathrm{NiO}$, tytanian glinu (układ ortorombowy), korund, rutyl,

- powłoka $\mathrm{NiMoAl} / \mathrm{ZrO}_{2}-30 \%$ mas. CaO: roztwór stały $\mathrm{Ni}, \mathrm{NiO}, \mathrm{ZrO}_{2}$ oraz $\mathrm{CaZrO}_{3}$ krystalizujące w układzie ortorombowym,

- średnia wartość twardości jest zbieżna z danymi dla powłok natryskiwanych metodą plazmową,

- wartość porowatości zależy silnie od udziału proszku metalicznego w mieszaninie proszków stosowanych do natryskiwania,

- wartości parametrów struktury geometrycznej powierzchni malały ze wzrastającą zawartością materiału ceramicznego. 


\section{Literatura}

[1] Hejwowski T.: Studium procesów zużywania erozyjnego, ściernego i zmęczenia cieplnego elementów maszyn oraz kształtowanie struktur o korzystnych właściwościach eksploatacyjnych. Wydawnictwa Politechniki Lubelskiej, Lublin 2003.

[2] Mc Pherson R.: A review of microstructure and properties of plasma sprayed ceramic coatings. Surface and Coatings Technology 39/40 (1989).

[3] Li C., Ohmori A., McPherson R.: The relationship between microstructure and Young's modulus of thermally sprayed ceramic coatings. Journal of Materials Science 32 (1997).

[4] Li C.-J., Ohomori A.: The lamellar structure of a detonation gun sprayed $\mathrm{Al}_{2} \mathrm{O}_{3}$ coating. Surface and Coatings Technology 82 (1996).

[5] Hejwowski T.: Comparative study of thermal barrier coatings for internal combustion engine. Vacuum 85 (2007).

[6] Jin Z-H., Batra R.C.: Thermal shock cracking in a metal-reinforced ceramic matrix composite. Engineering Fracture Mechanics 62 (1999).

[7] Gudmundsson B., Jacobson B., Berglin L., L'Estrade L., Gruner $\mathrm{H}$.: Microstructure and erosion resistance of vacuumplasma-sprayed Co-Ni-Cr-Al-Y/Al $\mathrm{O}_{3}$ composite coatings. Materials Science and Engineering A108 (1989).

[8] Wang B., Lee S.W.: Erosion-corrosion behavior of HVOF $\mathrm{NiAl}-\mathrm{Al}_{2} \mathrm{O}_{3}$ intermetallic-ceramic coating. Wear 239 (2000).

[9] Ramm D.A.J., Hutchings I.M., Clyne T.W.: Erosion resistance and adhesion of composite metal/ceramic coatings produced by plasma spraying. Journal de Physique IV 3 (1993).

[10] Mahesh R.A., Jayaganthan R., Prakash S.: Microstructural chracteristics and mechanical properties of HVOF sprayed $\mathrm{NiCrAl}$ coating on superalloys. Journal of Alloys and Compounds 468 (2009)

[11] Mahesh R.A., Jayaganthan R., Prakash S.: Microstructural characterization and hardness evaluation of HVOF sprayed $\mathrm{Ni}-5 \mathrm{Al}$ coatings on $\mathrm{Ni}$ - and Fe-based superalloys. Journal of Materials Processing Technology 209 (2009).

[12] Hejwowski T.: Degradation of aluminium titanate based TBC in thermal fatigue and diesel engine tests. Applied Plasma Science (12) 2004.

[13] Górski L.: Przemiany fazowe w materiałach ceramicznych na bazie $\mathrm{Al}_{2} \mathrm{O}_{3} \mathrm{~W}$ warunkach natryskiwania plazmowego i wygrzewania stacjonarnego - część II - układ $\mathrm{Al}_{2} \mathrm{O}_{3}-\mathrm{TiO}_{2}$. Inżynieria Materiałowa (1995) 1.

[14] Brandt R.: Thermal diffusivity measurements on plasma-sprayed Ca-stabilized $\mathrm{ZrO}_{2}$. High Temperatures - High Pressures 13 (1987).

[15] Chwa S.O., Klein D., Toma F.L., Bertrand G., Liao H., Coddet C., Ohmori A.: Microstructure and mechanical properties of plasma sprayed nanostructured $\mathrm{TiO}_{2}$-Al composite coatings. Surface and Coatings Technology 194 (2005).
[16] Schwingel D., Taylor R., Haubold T., Wigren J., Gualco C.: Mechanical and thermophysical properties of thick PYSZ thermal barrier coatings: correlation with microstructure and spraying parameters. Surface and Coatings Technology 108-109 (1998).

[17] Sodeoka S., Suzuki M., Ueno K., Sakuramoto H., Shibata T., Ando M.: Thermal and mechanical properties of $\mathrm{ZrO}_{2}-\mathrm{CeO}_{2}$ plasma sprayed coating. Journal of Thermal Spray Technology 6 (3) (1997).

[18] Alcala J., Gaudette F., Suresh S., Sampath S.: Instrumented spherical micro-indentation of plasma sprayed coatings. Materials Science and Engineering A316 (2001).

[19] Fervel V., Normand B., Coddet C.: Tribological behavior of plasma sprayed $\mathrm{Al}_{2} \mathrm{O}_{3}$-based cermet coatings. Wear 230 (1999).

[20] Pan C., Xu X.: Microstructural characteristics in plasma sprayed functionally graded $\mathrm{ZrO}_{2} / \mathrm{NiCrAl}$ coatings. Surface and Coatings Technology 162 (2003)

[21] Sampath S., Jiang X.Y., Matejicek J., Leger A.C., Vardelle A.: Substrate temperature effects on splat formation, microstructure development and properties of plasma sprayed coatings. Part I: Case study for partially stabilized zirconia. Materials Science and Engineering A272 (1999).

[22] Kurella A., Dahotre N.B.: Laser induced multi-scale textured zirconia coating on Ti-6Al-4V. J. Mater. Sci: Mater Med 17 (2006).

[23] Li J.F., Li L., Stott F.H.: Fractal characteristics of apparent pores present on polished cross sections of alumina coatings prepared by laser-assisted flame hybrid spraying. Thin Solid Films 453-454 (2004).

[24] Su Y., Lei W.-S.: Relationship between fracture toughness and fractal dimension of fracture surface of steel. International Journal of Fracture 106 (2000).

[25] Celli A., Tucci A., Esposito L., Palmonari C.: Fractal analysis of cracks in alumina-zirconia composites. Journal of European Ceramic Society 23 (2003).

[26] Amada S., Hirose T.: Planar fractal characteristics of blasted surfaces and its relation with adhesion strength of coatings. Surface and Coatings Technology 130 (2000).

[27] Amada S., Yamada H.: Introduction of fractal dimension to adhesive strength evaluation of plasma-sprayed coatings. Surface and Coatings Technology 78 (1996).

[28] Kwaśny W., Dobrzański L.A., Pawlyta M., Gulbiński W.: Fractal nature of surface topography and physical properties of the coatings obtained using magnetron sputtering. Journal of Materials Processing Technology 157-158 (2004).

[29] Reisel G., Heimann R.B.: Correlation between surface roughness of plasmas-prayed chromium oxide coatings and powder size distribution: a fractal approach. Surface and Coatings Technology 185 (2004). 